\title{
SELECTED LOGISTICS PROCESSES IN THE FLOW OF PERISHABLE PRODUCTS
}

\author{
Maciej Koszorek \\ University of Zielona Góra, Institute of Management and Quality Sciences, Department of Logistics and Information \\ Systems, ul. Podgórna 50, 65-246 Zielona Góra, Poland, koszorek.maciej@ gmail.com \\ Katarzyna Huk \\ University of Zielona Góra, Institute of Management and Quality Sciences, Department of Logistics and Information \\ Systems, ul. Podgórna 50, 65-246 Zielona Góra, Poland, \\ k.huk@wez.uz.zgora.pl (corresponding author)
}

Keywords: logistics, processes of logistics, perishable products

Abstract: Logistics processes and supply chains are widely viewed. The dependencies and conditions of their functioning depend primarily on the products that are in the circulation of these activities. Product flows in supply chains can be grouped according to certain types of products and their specificity of transport and storage. It will also determine the differences in the processes that will be used and their specificity. The article deals with three types of products: milk, fruit and human blood. Contrary to appearances, these products are very similar to each other, and the specificity of logistics activities is the same for this group. This is a group that has been called perishable products. Their specificity lies in the need to quickly deliver them to the final consumer so that they do not lose their properties. Most of this is possible thanks to the use of cold stores and efficient supply chains. The article compares the logistic processes used in the movement of human blood along supply chains. The aim of the article is therefore to analyse and compare the logistics processes used in the supply chains of blood and perishable products. The article is literary and empirical in nature and is based on a literature analysis, case study, participant observation and reports. The study presents the supply chain for perishable products, indicates the specificity of individual logistics processes and presents common features for this group of products. The Regional Centre for Blood Donation and Blood Treatment (RCKiK in Poland) in Zielona Góra was used as a case study. It is the organization that primarily manages the blood flow from donors to hospitals and other organizations right down to the ultimate consumer-patient.

\section{Introduction}

Shaping a good quality product that meets the expectations and needs of customers requires many related activities. These activities relate not only to the processing of raw materials, materials or semi-finished products, but also to many additional activities, such as proper transport, storage and information management. Logistics activities are determined by the specific characteristics of the products and the conditions that must be met so that they do not lose them. Many product groups do not require special treatment - they are resistant to weather conditions and other potentially harmful factors, however, one can distinguish those for which inadequate protection may affect the loss of quality or performance. The logistics task is to provide this protection at every stage of the flow. Requirements that often have to be met are unique to specific products, but to formulate general principles and notice similarities between flows that can later be used as reference points in the planning process, they are classified. An example of the classification of products according to the special challenges posed by logistics are perishable products that are sensitive not only to environmental conditions, but also to the passage of time. The article presents the flow of human blood in the supply chain. It has been compared to perishable products like milk and fruit.
Their specificity lies in the fast flow and minimization of the loss of value of these products. This article uses a case study of blood flow based on an organization that manages these activities from blood donors to patients. It is the Regional Centre for Blood Donation and Blood Treatment (RCKiK in Poland) in Zielona Góra.

The aim of the article is therefore to analyse and compare the logistics processes used in the supply chains of blood and perishable products. The article is literary and empirical in nature and is based on a literature analysis, case study, participant observation and reports. The Regional Centre for Blood Donation and Blood Treatment (RCKiK) in Zielona Góra was used as a case study.

\section{Logistics processes in business management}

The company's activity is based on repetitive, successive activities that are to bring a specific result. They make up the process, i.e. "a logical sequence of consecutive or parallel activities, the implementation of which leads to meeting the client's expectations - both internal and external - by providing him with a product, service, documentation in accordance with his requirements" [1]. Before the product reaches the recipient, it must go through a series of processes that can shape it directly or indirectly. 
Due to the multitude of processes, many researchers tried to systematize them based on various criteria. M. Porter proposed a simple division into basic and auxiliary processes. Basic processes are associated with the preparation of production and delivery of appropriate materials, product production, sales and distribution, marketing and after-sales services. Ancillary processes are management of the entire unit, its resources, as well as improvement activities [2]. Another classification was presented by J.G. Miller and T.E. Vollman, who distinguished the following groups of processes [3]:
- logistics - consisting in initiating, conducting and coordinating material flows,

- balancing - activities adapting the funds involved to real demand, such as purchases, material requirements planning, task delegation,

- quality - related to process control, compliance with technical requirements,

- information - related activities aimed at ongoing updating of data in the organization's system.

Table 1 Logistic processes and activities

\begin{tabular}{|c|c|}
\hline Process & Actions \\
\hline Transport & $\begin{array}{l}\text { - choice of transport type and level of transport services, } \\
\text { - establishing the transport network, } \\
\text { - developing a vehicle traffic schedule, } \\
\text { - selection of specific transport equipment, } \\
\text { - handling complaints, } \\
\text { - control of transport rates, }\end{array}$ \\
\hline $\begin{array}{l}\text { Shaping the level and } \\
\text { structure of inventories }\end{array}$ & $\begin{array}{l}\text { - formulation of a policy on the stock of raw materials, materials and finished products, } \\
\text { - development of short-term sales forecasts, } \\
\text { - definition of the inventory structure at storage points, } \\
\text { - determining the number, size and location of storage points, }\end{array}$ \\
\hline Logistic customer service & $\begin{array}{l}\text { - agreeing on the scope of customer needs and requirements for the customer service system, } \\
\text { - anticipating customer responses to an agreed service system, } \\
\text { - determining the final quality of customer service level, }\end{array}$ \\
\hline Storage & $\begin{array}{l}\text { - determining the demand for storage space, } \\
\text { - inventory distribution design, } \\
\text { - receiving, completing and loading materials to and from the warehouse, }\end{array}$ \\
\hline Packaging management & $\begin{array}{l}\text { - choice of packaging to facilitate: } \\
\circ \text { for loading, unloading and reloading operations, } \\
\circ \text { about storage processes, } \\
\circ \text { for protection against damage. }\end{array}$ \\
\hline
\end{tabular}
Source: [4].

Logistics processes on which this study focuses are carried out from the moment of obtaining raw materials to delivering the final product to the consumer. They rely not only on the physical movement of materials, but also on proper storage, protection and management of information. Many activities performed in the organization would be impossible without proper logistic service because it in some sense binds all the activities of the company. S. Twaróg identified five logistic processes and activities performed within them, which are presented in Table 1.

These processes as a whole come down to the optimal flow of raw materials, materials and finished products and related information at the lowest possible cost, appropriate quantity, quality, time and place of delivery [5]. Despite one clearly defined goal, there is no universal way of performing individual processes. Many of the conditions set depend on the properties of a given raw material, material or finished product. Efficient execution of logistics processes is particularly important in the case of products sensitive to external factors. Time is important here and ensuring appropriate conditions at each stage of the flow, as well as the information message accompanying physical flows. This type of logistics must be applied to perishable products.

\section{Characteristics of the logistics of perishable products}

The classification of products to the group of perishable products is not clear-cut and does not depend on a specific industry or product type. Some researchers attribute to it only products that spoil and, as a result, deteriorate over time, which starts from the moment they are produced. Additionally, they can be divided into those that have a predetermined shelf life, such as milk, blood components, yoghurts, and those of various shelf life, such as fresh fruit and vegetables [6]. In addition to the time criterion, they require appropriate conditions during processing, storage and transport. In other literature, demand conditions were also taken into account and the group of perishable products additionally classified clothing subject to temporary fashion and products replaced with the rapid development of technology (mainly electronics) [7]. In both cases, transportation must be fast and efficient to deliver the flow items at the right time and to the right 
place, but products that lose their value due to deterioration require additional protection and the right temperature. The situation is similar in the case of storage and inventory management - the element that differentiates both types is the need to provide protection and optimal conditions for products that lose their properties, and the approach to inventory is the same - they should be shaped in such a way as to meet the demand, but at the same time avoid wastage resulting from the destruction of products or changes in consumer preferences, which boils down to minimizing inventories. Another important issue that perishable product logistics must deal with waste management. Due to the fact that some of the products may become worthless very quickly, there is no way to completely avoid losses, therefore actions aimed at neutralizing waste are necessary. A particular challenge is that some of the perishable products can become hazardous waste, such as medicines or electronics. The last highlighted element is information management, which is crucial in the event of unstable demand typical for this type of product. By monitoring the needs and changing preferences of consumers, the volume of flows can be adjusted to avoid losses. Moreover, the information message accompanying the physical flows can improve them and avoid errors. In order to further characterize some logistic processes of perishable products, three exemplary product groups were selected milk, blood and soft fruit.

\section{Identification of logistic processes in the flow of perishable products on the example of milk, blood and soft fruit}

\subsection{Selected logistic processes in the flow of milk in supply chains}

The key role of logistics begins with the flow of the main raw material of dairy products - milk, which before processing is particularly exposed to time, external factors and very rapid loss of value. Once harvested, the milk is cooled and then collected from farms and transported to the dairy plant in two ways [8]:

- directly - from the producer to the dairy plant with the use of tank trucks,

- indirectly - from the producer, through a collection point, to a dairy plant, most often by means of cisterns, tanks or containers.

Due to the high sensitivity of the product to external factors, both transport and previous storage must meet the requirements for temperature and proper hygiene. Pursuant to the requirements of REGULATION (EC) No 853/2004 of the European Parliament and of the Council of 29 April 2004 laying down specific hygiene rules for food of animal origin, raw milk must be chilled to a temperature not exceeding $8{ }^{\circ} \mathrm{C}$ immediately after collection, if it is to be picked up within one day and $6{ }^{\circ} \mathrm{C}$ if it is not picked up every day. During transport, proper hygiene should be maintained (especially with regard to maintaining cleanliness of equipment and containers, which should be washed and disinfected at least once a day), as well as such conditions that when reaching the plant of destination, the temperature of the raw material does not exceed $10^{\circ} \mathrm{C}[9]$. Once at the processing plant, the raw material is typically processed within 24 hours. As with any product that loses its value, time is crucial here to avoid potential damage or loss of quality. Before processing, the milk is temporarily stored in storage tanks or silos equipped with thermal insulation, liquid level indicator, temperature indicator and a stirrer. The temperature during the storage process should be around $4{ }^{\circ} \mathrm{C}[10]$. After the above-mentioned logistic processes are correctly carried out, good quality raw material can be used for further production. After processing, milk does not lose value as quickly as raw milk, but dairy products still have a limited shelf life and need to be stored under appropriate conditions - on average at a temperature of 2 to $6{ }^{\circ} \mathrm{C}$, with the exception of UHT milk and milk drinks in cartons, which retain their properties at temperatures up to $25^{\circ} \mathrm{C}$.

In addition to the physical flows, an important element is the communication of information and demand planning, which is difficult due to seasonal fluctuations in the demand and supply of milk. The supply is increased in spring and summer, and the demand is increased in the winter months [10]. Effective information management regarding winter demand allows stocks of already processed products to be shaped in such a way as to meet customer expectations by taking advantage of the surplus in the spring and summer period.

\subsection{Selected logistic processes in the flow of blood and its preparations in supply chains}

Another product that is sensitive to the passage of time and external conditions is blood, which is used in blood therapy after proper preparation and processing. Before it reaches its destination, it must go through a series of activities supported by logistic processes. Once collected from a donor, blood must be stored in single-use plastic containers that contain an anti-clotting solution. Transport to the Regional Blood Donation and Blood Treatment Centre (RCKiK in Poland) takes place at a temperature not exceeding 10 [11], and must also take place in a key time of less than 8 hours, during which blood should be processed in order to preserve the values of individual components [12]. After reaching the RCKiK, the blood goes to special centrifuges as soon as possible, where it is separated into three components: concentrate of red blood cells, plasma and buffy coat, which is used to obtain a concentrate of platelets. The shelf life and storage temperature requirements for the selected preparations are as follows [11]:

- red blood cell concentrates (RBC) - must be stored in a refrigerator at 2 to $6^{\circ} \mathrm{C}$, maximum 35 days in CPDA preservative fluid or 42 days in adenine-free citratephosphate-glucose fluid (CPD); 
- fresh frozen plasma - must be frozen within a maximum of 6 hours from collection and stored at $18^{\circ} \mathrm{C}$ or lower. In case of ensuring the temperature of -30 , the shelf life of the preparation is 2 years, and if it is higher - one year;

- $\quad$ platelet cell concentrates - the storage temperature is 20 to $24^{\circ} \mathrm{C}$, and the maximum storage time - 72 hours or 5 days in breathable polyolefin containers;

- granulocytic concentrate - the shelf life of the preparation if stored at 20 to $24^{\circ} \mathrm{C}$ is 24 hours.

Unlike the raw material, not all preparations require refrigeration, but this translates into a significant reduction in their shelf life.

Stock formation in the case of blood and blood preparations is difficult due to the unpredictable nature of supply and demand, which cannot be estimated by market research as is the case with many other products. Shaping the supply can take place through blood donation campaigns and other similar events, but the demand cannot be directly influenced [13]. The RCKiK experience in Zielona Góra shows that the demand for blood was often greater than the supply, but there were also situations when it was necessary to cancel the departure action due to too much supply of some blood components, which in a given period was not reflected in the demand and could be wasted. The uncertainty related to the blood demand cannot be reduced, but its seasonality can be used for estimation purposes. In summer, the supply of blood is reduced due to the fact that many blood donors decide not to donate it during holidays or vacation, and at the same time the demand increases, which is caused by the increase in the number of accidents [14]. It is precisely in the statistics on the number of car accidents that one can see periods when the demand for blood is increased and requires appropriate logistic preparation, i.e. winter breaks and holidays.

\subsection{Selected logistic processes in the flow of soft fruit in supply chains}

Another distinguished product from the perishable group are soft fruits, such as blueberries, currants, strawberries and blueberries. After picking them up from the production farm, transport can take place in two ways:

- directly to the processing plant;

- indirectly through a collection point to the processing plant.

An important issue in this flow is to keep the product as short as possible in non-refrigerated conditions [15]. The recommended temperatures and duration of transport processes, based on the example of raspberries and wild strawberries, are from -1 to $3{ }^{\circ} \mathrm{C}$ for transport not longer than 24 hours [16]. After reaching the processing plant, the fruit must be processed as soon as possible in order to maintain its high quality. The maximum storage period is not specified with one hundred percent accuracy, because, as it was noted earlier, fruits are perishable products in various periods of time, however, according to the soft fruit, they are most often suitable for a maximum of several days' storage at a temperature of about $0{ }^{\circ} \mathrm{C}$ (without a controlled atmosphere) [17]. After processing, most fruit preserves, such as jams or pasteurized juices, can be stored for several months without the need to provide them with special conditions, but there are exceptions, such as frozen fruit, which lose their value very quickly without ensuring the appropriate temperature. The optimal storage temperature for frozen soft fruit is $-20{ }^{\circ} \mathrm{C}$ [18]. As in the case of other products distinguished in this chapter, stocking is based on seasonality, as fresh soft fruit is harvested in Poland during the summer period and preserves are accumulated during this time.

\section{Comparative analysis of the logistics processes of the distinguished perishable products- results of research}

In the above-mentioned examples of processes, many similarities can be identified, which result from the specific conditions that must be met by logistics in order to maintain the highest quality and avoid loss of value of the products. The comparison of selected aspects of the flow of milk, blood and soft fruit is presented in Table 2.

Table 2. Comparison of logistic processes in the flow of milk, blood and soft fruit

\begin{tabular}{|c|c|c|c|}
\hline Logistics process & Milk & Blood and its components & Soft fruit \\
\hline $\begin{array}{l}\text { Transport before } \\
\text { raw material } \\
\text { processing }\end{array}$ & $\begin{array}{l}- \text { While maintaining the cold } \\
\text { chain, } \\
\text { - At a temperature of not more } \\
\text { than } 10^{\circ} \mathrm{C} \text {, } \\
- \text { Up to } 48 \text { hours. }\end{array}$ & $\begin{array}{l}\text { - While maintaining the cold chain, } \\
\text { - At a temperature of not more than } \\
10{ }^{\circ} \mathrm{C} \text {, } \\
\text { - Less than } 8 \text { hours. }\end{array}$ & $\begin{array}{l}\text { - While maintaining the cold } \\
\text { chain, } \\
\text { - At a temperature of }-1 \text { to } 3{ }^{\circ} \mathrm{C} \text {, } \\
\text { - Up to } 24 \text { hours. }\end{array}$ \\
\hline $\begin{array}{l}\text { Storage before } \\
\text { raw material } \\
\text { processing }\end{array}$ & $\begin{array}{l}\text { - In storage tanks or tank silos, } \\
\text { - At a temperature of approx. } 4 \\
{ }^{\circ} \mathrm{C} \text {, } \\
\text { - About } 24 \text { hours. }\end{array}$ & $\begin{array}{l}\text { - No pre-storage, processing as soon } \\
\text { as possible, } \\
\text { - If necessary, at a temperature of } \\
\text { not more than } 10{ }^{\circ} \mathrm{C} \text {. }\end{array}$ & $\begin{array}{l}\text { - In storage or cold stores, } \\
\text { - At a temperature of }-1 \text { to } 2{ }^{\circ} \mathrm{C} \text {, } \\
\text { - A maximum of several days. }\end{array}$ \\
\hline $\begin{array}{l}\text { Storage after } \\
\text { processing raw } \\
\text { materials }\end{array}$ & $\begin{array}{l}\text { - In storage rooms or cold stores } \\
\text { (depending on the processing), } \\
\text { - At room temperature or } 2 \text { to } 6 \\
{ }^{\circ} \mathrm{C} \text {, } \\
\text { - Shelf life varied, from approx. }\end{array}$ & $\begin{array}{l}\text { - In cold rooms, freezers, mixers or } \\
\text { on storage racks, } \\
\text { - At the temperature of } 2-6^{\circ} \mathrm{C} \text {, } \\
\text { below }-18^{\circ} \mathrm{C} \text { or } 20-24{ }^{\circ} \mathrm{C} \text {, } \\
\text { - Shelf life varied, from } 24 \text { hours }\end{array}$ & $\begin{array}{l}\text { - In cold rooms or storage rooms, } \\
\text { - At room temperature, approx. } 5 \\
{ }^{\circ} \mathrm{C} \text { (fresh juice) or } 20{ }^{\circ} \mathrm{C} \text { (frozen } \\
\text { fruit), } \\
\text { - Shelf life varied, from about } 3\end{array}$ \\
\hline
\end{tabular}


SELECTED LOGISTICS PROCESSES IN THE FLOW OF PERISHABLE PRODUCTS

Maciej Koszorek; Katarzyna Huk

\begin{tabular}{|l|l|l|l|}
\hline Logistics process & \multicolumn{1}{|c|}{ Milk } & \multicolumn{1}{|c|}{ Blood and its components } & \multicolumn{1}{c|}{ Soft fruit } \\
\hline & $\begin{array}{l}\text { 2 weeks (cottage cheese) up to 6 } \\
\text { months in the case of hard } \\
\text { cheese. }\end{array}$ & $\begin{array}{l}\text { (platelet cell concentrate) to 3 years } \\
\text { (freshly frozen plasma). }\end{array}$ & $\begin{array}{l}\text { days (fresh juices) to about a year } \\
\text { (jams). }\end{array}$ \\
\hline $\begin{array}{l}\text { Logistic customer } \\
\text { service }\end{array}$ & $\begin{array}{l}\bullet \text { Optimization of delivery time, } \\
\text { Ensuring freshness and } \\
\text { reliability of supplies. }\end{array}$ & $\begin{array}{l}\bullet \text { Optimization of delivery time, } \\
\text { Striving for reliability of deliveries } \\
\text { to the rescue". }\end{array}$ & $\begin{array}{l}\text { - Ontimization of delivery time, } \\
\text { reliability of supplies. }\end{array}$ \\
\hline $\begin{array}{l}\text { Shaping the level } \\
\text { and structure of } \\
\text { stocks }\end{array}$ & $\begin{array}{l}\bullet \text { Based on seasonality, } \\
\text { Purchased at collection points } \\
\text { seasonality, directly at dairy plants. } \\
\text { or Obtained as part of voluntary } \\
\text { donations, collected in the RCKiK } \\
\text { stationary or by way of away } \\
\text { actions. }\end{array}$ & $\begin{array}{l}\bullet \text { Based on seasonality, } \\
\text { directly at processing plants. }\end{array}$ \\
\hline $\begin{array}{l}\text { Packaging } \\
\text { management }\end{array}$ & $\begin{array}{l}\text { Transport packaging - cisterns } \\
\text { tanks or containers. }\end{array}$ & $\begin{array}{l}\text { Transport packaging - plastic } \\
\text { packaging containing an anti- } \\
\text { clotting solution. }\end{array}$ & $\begin{array}{l}\text { Transport packaging - transport } \\
\text { boxes for soft fruit. }\end{array}$ \\
\hline
\end{tabular}

Source: own study based on: [9-11,15,16,19-21].

Although three different product groups have been selected, it can be seen that they all require a specific logistic approach. This is primarily determined by the critical time from the acquisition of the distinguished raw materials to their processing, in which they are particularly prone to loss of value, and the need to provide them with cooling conditions during transport and storage.

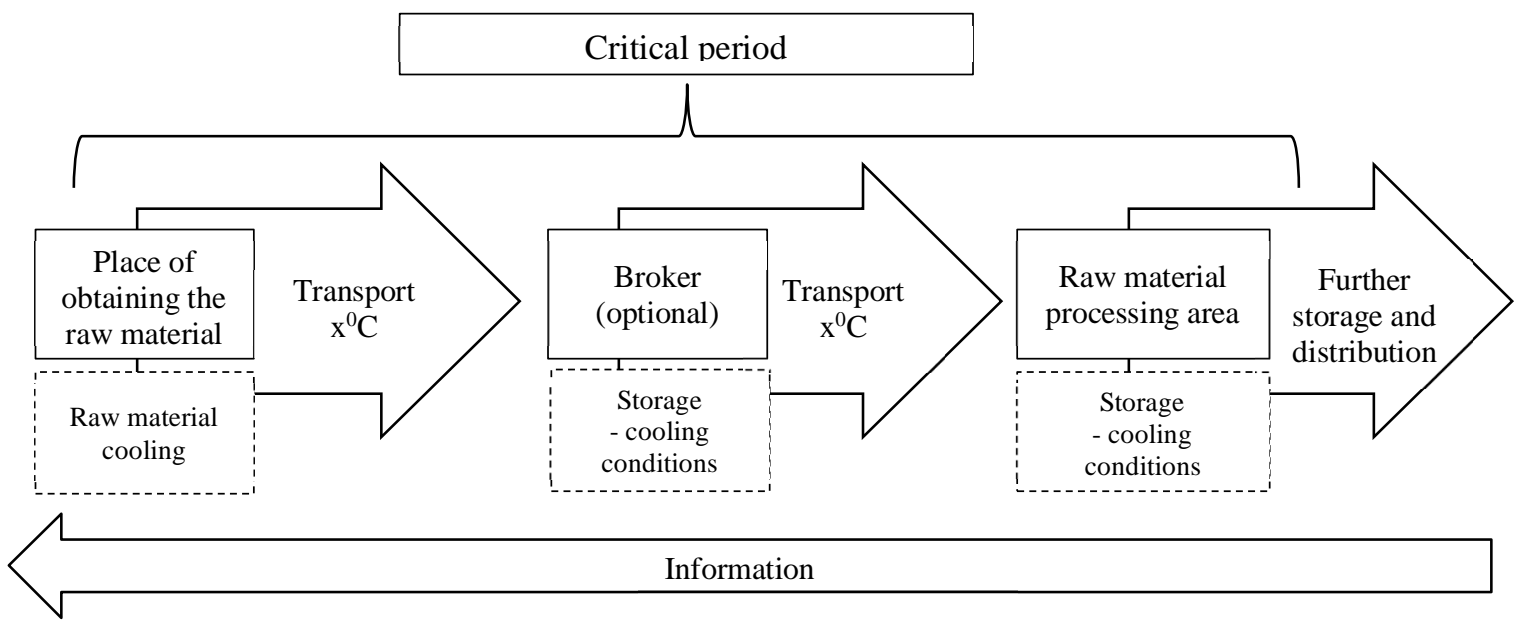

Figure 2 Diagram of logistic processes of perishable products in the supply chain

This is important because improper performance of logistic processes in this period may result in a reduction in the quality of the raw material and the finished product, and in the worst case - wasting it. After processing, the products are not so exposed to time and require various conditions (not necessarily refrigeration), so the greatest similarity should be seen at the stage of raw materials. Inventory management of all product groups is difficult due to their tendency to impairment and the need to rely on seasonality. Thanks to the conducted analysis, a general scheme of logistic processes from the moment of obtaining the raw material to its processing was formulated, which is shown in Figure 2.

The diagram shown above can be used as a reference for the flow of perishable products that are particularly sensitive to external influences and the time to processing, such as those presented in this paper.
In the case of perishable products, regardless of their type, it is important to:

- $\quad$ keeping products in an optimal place and cooling them,

- the shortest possible transport time,

- appropriate transport and storage conditions tailored to the specificity of the product,

- identifying individual products in supply chains,

- systems for identifying and checking the condition of products on the way in supply chains,

- the flow of relevant information at each stage of the chain,

- shortening the time of transport and storage until the products are processed,

- ensuring appropriate measures to protect the freshness of products and their packaging,

- optimal inventory control cycle. 
However, it should be noted that all logistic processes in the supply chains regarding perishable products should be adjusted individually to given groups of goods. Their specificity and rapid depreciation of value implies the need to individually adjust logistics activities to product groups.

\section{Conclusion}

Providing the best quality is the overriding goal of every manufacturer, but to achieve it, it is not enough just to improve production and other processes that shape the product in a direct way. Efficiently carried out logistic processes condition the quality of the product at every stage of the flow, starting with obtaining the raw material, ending with creating inventories and delivering the finished product to the customer.

Classifying a product to the perishable group requires high efficiency and shortening the duration of logistics processes. Due to the large variety of products classified as perishable, different requirements are imposed in terms of ensuring the conditions or the use of appropriate packaging, but the main task of logistics remains the same - as the fastest possible flow in such a way as to minimize loss of quality.

The set research goal was achieved, the logistic processes of perishable products were identified and analysed. Thanks to the comparative analysis of the logistics processes of selected products, the common features were noticed and a general scheme was proposed showing them from the moment of obtaining the raw material to the storage and distribution of already processed products. In addition, in all analysed processes, a critical period was observed until the products were processed, and it was indicated as a time particularly important for logistics and shaping the final quality, which should be taken into account at the planning stage.

\section{References}

[1] SKRZYPEK, E.: Jakość i efektywność, Wydawnictwo UMCS, Lublin, 2002. (Original in Polish)

[2] PORTER, M.: Competitive Advantage, Free Press, Nowy Jork, 1985.

[3] MILLER J.G., VOLLMAN T.E., The Hidden Factory, Harvard Business Review No. 5, 1985.

[4] TWARÓG, S.: System logistyczny, in, Kauf S. (red.), Vademecum logistyki, Wydawnictwo Difin, Warszawa, 2016. (Original in Polish)

[5] KAWA, A., SOLECKI, B., ŚLIWKA, R.: Projekty usprawniające procesy logistyczne, Logistyka, Vol. 2009, No. 1, pp. 26-30, 2009. (Original in Polish)

[6] AMORIM, P., GUNTHER, H., ALMADA- LOBO, B.: Tackling Freshness in Supply Chain Planning of Perishable Products, VII ALIO/EURO, Workshop on Applied Combinatorial Optimization, Porto, 2011.

[7] NAGURNEY, A., YU, M., MASOUMI, A., NAGURNEY, L.: Networks Against Time: Supply
Chain Analytics for Perishable Products, Springer Science \& Business Media, Nowy Jork, 2013.

[8] RUDZIŃSKI, R., Organizacja logistyki w zakładach przetwórstwa mleka, [w:] Zeszyty Naukowe Uniwersytetu Przyrodniczo-Humanistycznego No. 87, Seria Administracja i Zarządzanie (14) 2010, Wydawnictwo UP-H, Siedlce, pp. 161-163, 2010. (Original in Polish)

[9] Parlament Europejski, Rada Unii Europejskiej, ROZPORZĄDZENIE (WE) NR 853/2004 Parlamentu Europejskiego i Rady z dnia 29 kwietnia 2004 r. ustanawiające szczególne przepisy dotyczace higieny $w$ odniesieniu do żywności pochodzenia zwierzęcego, [Online], Available: https://eurlex.europa .eu/LexUriServ/LexUriServ.do?uri=CONSLEG:2004 R0853:20110311:PL:PDF, [17 Feb 2020], 2004. (Original in Polish)

[10] NOWAKOWSKA - GRUNT, J., KOT, S.: System logistyczny $w$ przedsiębiorstwach przemystu mleczarskiego [w:] Nowicka-Skowron M. (red.), Prognozowanie $i$ modelowanie systemów logistycznych $w$ przemyśle mleczarskim, Wydawnictwa Politechniki Częstochowskiej, Częstochowa, pp. 106-115, 2004. (Original in Polish)

[11] NIECHWIADOWICZ - CZAPKA, T., KLIMCZYK, A.: Leczenie krwia, Wydawnictwo PZWL, Warszawa, 2011. (Original in Polish)

[12] KALWASIŃSKA, W.: Droga krwi [Online], Available: https://www.gov.pl/web/nck/droga-krwi, [21 Feb 2020], 2019. (Original in Polish)

[13] SZOŁTYSEK, J., TWARÓG, S.: Gospodarowanie zasobami krwi jako nowy obszar stosowania logistyki, Gospodarka Materiatowa i Logistyka, Vol. 2009, No. 7, pp. 12-17, 2009. (Original in Polish)

[14] Krwiodawcy, W wakacje zawsze brakuje krwi [Online],

Available: https://krwiodawcy.org/wakacje-zawszebrakuje-krwi, [23 Feb 2020], 2016. (Original in Polish)

[15] DOMARADZKI, A.: Wsparcie logistyczne W obszarach produkcji i przetwórstwa owoców miękkich, Logistyka, Vol. 2012, No. 4, pp. 899-900, 2012. (Original in Polish)

[16] Poradnik spedytora, Drogowy transport owoców [Online], Available: http://poradnikspedytora.pl/201 3/drogowy-transport-owocow/, [23 Feb 2020], 2013. (Original in Polish)

[17] ZAGÓRSKA, K., Jak przechowywać owoce borówki, aby wydtużý okres ich podaży na rynku? [Online], Available: http://www.sadyogrody.pl/logistyka_i_op akowania/107/jak_przechowywac_owoce_borowki_ aby_wydluzyc_okres_ich_podazy_na_rynku,4281.ht ml, [24 Feb 2020], 2016. (Original in Polish)

[18] GRABOWSKA, B.: Mrożenia owoców miękkich Part. 1. Normy i Przepisy [Online], Available: https://www.chlodnictwoiklimatyzacja.pl/artykuly/2 30-wydanie-06-2014/3196-mrozenia-owocow- 
miekkich-cz-1-normy-i-przepisy.html, [24 Feb 2020], 2014. (Original in Polish)

[19] SZOŁTYSEK, J., TWARÓG, S., Korzyści ze stosowania logistyki W zarządzaniu systemem cywilnego krwiodawstwa w Polsce, Logistyka, Vol. 2010, No. 6, pp. 14-17, 2010. (Original in Polish)

[20] Ministerstwo Zdrowia, DZ. U. Min. Zdr. 2017.63 [Online], Available: http://dziennikmz.mz.gov.pl/api /DUM_MZ/2017/63/journal/3870, [17 Apr 2020], 2017. (Original in Polish)
[21] Dziennik Ustaw Dz.U. 2015 poz. 667 [Online], Available: http://prawo.sejm.gov.pl/isap.nsf/downlo ad.xsp/WDU20150000667/O/D20150667.pdf, [17 Apr 2020], 2020. (Original in Polish)

\section{Review process}

Single-blind peer review process. 